\title{
Intervals and Number of Applications of Acibenzolar-S-Methyl for the Control of Bacterial Spot on Processing Tomato
}

\author{
Nadson de Carvalho Pontes, Programa de Pós-Graduação em Olericultura, Instituto Federal Goiano, Morrinhos, GO, 75650-000, Brazil; \\ Abadia dos Reis Nascimento, Programa de Pós-Graduação em Agronomia, Universidade Federal de Goiás, Goiânia, GO, 74690-900, \\ Brazil; Adelmo Golynski, Programa de Pós-Graduação em Olericultura, Instituto Federal Goiano, Morrinhos, GO, 75650-000, Brazil; Luiz \\ Antonio Maffia and José Rogério de Oliveira, Programa de Pós-Graduação em Fitopatologia, Universidade Federal de Viçosa, Viçosa, MG, \\ 36570-000, Brazil; and Alice Maria Quezado-Duval, Centro Nacional de Pesquisa de Hortaliças, Empresa Brasileira de Pesquisa Agropecuá- \\ ria, Brasília, DF, 70351-970, Brazil
}

\begin{abstract}
Pontes, N. C., Nascimento, A. R., Golynski, A., Maffia, L. A., Oliveira, J. R., and Quezado-Duval, A. M. 2016. Intervals and number of applications of acibenzolar-S-methyl for the control of bacterial spot on processing tomato. Plant Dis. 100:2126-2133.

Acibenzolar-S-methyl (ASM) is a plant activator that triggers systemic acquired resistance that is labeled for use in Brazil for managing tomato bacterial spot. The aim of this study was to define the optimum relationship between interval and number of applications of ASM for the most efficacious control of bacterial spot on processing tomato. Four intervals between applications $(4,7,10$, and 14 days) and four application frequencies $(4,6,8$, and 10 applications) were evaluated in five trials performed between 2010 and 2011 in Brasília, Distrito Federal, and in Morrinhos, in the state of Goiás. Copper hydroxide $(\mathrm{CH})$ was applied after ASM applications to complete 13 applications per growing season. Two check treatments were added: standard $\mathrm{CH}$ weekly applications and untreated. The following variables were evaluated: severity of bacterial spot, yield, percentage of ripe and rotten fruit, soluble solids content, and the benefit/ cost ratio. Disease severity varied between treatments in three trials

and yield varied in two trials. A greater number of applications resulted in a reduction of bacterial spot, and the ideal interval between applications was between 8 to 10 days. However, there was a reduction in yield with 10 ASM applications. The temporal effect of ASM applications on bacterial spot severity was evaluated under greenhouse conditions. Reduction in disease severity was observed up to 6 days following ASM application. Additionally, the weekly treatment of seven applications of ASM followed by six applications of $\mathrm{CH}$ was compared with a standard program of $\mathrm{CH}$ under commercial production conditions in Itaberaí, Goiás, where bacterial spot occurred naturally. The program with ASM and $\mathrm{CH}$ resulted in significantly less foliar disease severity than the standard program, which did not result in yield gains. In addition, no differences were detected between the two programs for soluble solids content, industrial yield, plant height, and percentage of ripe and rotten fruit.
\end{abstract}

Brazil is the eighth largest producer of processing tomato (Solanum lycopersicum L.) in the world, with an estimated production of 1.3 million tons for the 2015 harvest (WPTC 2015). The production areas are mainly concentrated in the central region of Brazil, with the state of Goiás accounting for approximately $80 \%$ of the national production (Melo and Fonte 2011). Where sprinkler irrigation is used, bacterial spot is one of the most destructive diseases of processing tomato crops in the country (Quezado-Duval et al. 2013). The disease causes necrotic leaf spots that progress to defoliation, and can lead to reduced yield and increase in sunscald of fruit, which reduces quality.

Bacterial spot of tomato has been associated with four species of Xanthomonas: Xanthomonas euvesicatoria (race T1), X. perforans (races T3 and T4), X. vesicatoria (race T2), and $X$. gardneri (race T2 behavior) (Jones et al. 2004; Potnis et al. 2015), which are all found in Brazil (Quezado-Duval et al. 2005). Tomato crop debris, seedlings from infected seeds, volunteer plants, and weeds are potential inoculum sources for the disease (Araújo et al. 2015; Jones et al. 1986).

Despite the identification of resistance sources in various studies (Stall et al. 2009), with both race-specific and broad-spectrum effects, processing tomato varieties with complete resistance to bacterial spot are not currently commercially grown in Brazil. Thus, chemical control, the use of hybrids with quantitative resistance which have been identified in some commercial hybrids (QuezadoDuval et al. 2014), and crop rotation are the strategies applied by

Corresponding author: A. M. Quezado-Duval;

E-mail: alice.quezado@embrapa.br

Accepted for publication 16 April 2016.

http://dx.doi.org/10.1094/PDIS-11-15-1286-RE

(C) 2016 The American Phytopathological Society farmers and processing tomato companies to mitigate bacterial spot losses.

Copper compounds and antibiotics were the early chemicals labeled for tomato bacterial spot control in Brazil, and were intensively used worldwide (Quezado-Duval and Lopes 2010). However, the emergence of pathogen populations tolerant to these chemicals (Adaskaveg and Hine 1985; Mirik et al. 2007) has led to the search for new chemicals for bacterial spot management, such as plant resistance inducers (Cavalcanti et al. 2006b; Coqueiro et al. 2011; Fontenelle et al. 2011; Lucas et al. 2012; Obradovic et al. 2004). In Brazil, acibenzolar-S-methyl (ASM; = benzothiadiazole, Bion 500 WG, 50\% ASM; Syngenta Crop Protection) is labeled for the control of bacterial spot in tomato (Quezado-Duval and Lopes 2010).

ASM is an analog of salicylic acid that acts as an activator of systemic acquired resistance (SAR). Its efficacy for tomato bacterial spot control has been demonstrated in several greenhouse and field experiments (Abbasi et al. 2002a,b; Louws et al. 2001; Huang et al. 2012; Obradovic et al. 2004). However, in many cases, the reduction in disease severity does not always translate into an increase in yield, and plant growth delay has also been reported (Abbasi et al. 2002b; Gilardi et al. 2010; Louws et al. 2001).

There is an energy cost associated with the induction of resistance due to the reallocation of metabolites and energy from other processes, such as growth and reproduction (Walters and Fountaine 2009). To be economically efficient, an ASM application program should lead to a balance between the energy cost and the disease management, which should be cost effective. Moreover, it should give an equivalent or better benefit/cost ratio, relative to the standard copper-based program. Options for reaching this goal would be to decrease the number of applications of ASM in the growing season or to adjust the rates and frequency of application. However, the effect of resistance induction triggered by ASM persists for only a short period of time and, thus, requires multiple applications (Herman et al. 2007; 
Louws et al. 2001). For example, according to Huang et al. (2012), ASM was effective in weekly applications but not when it was applied biweekly. Thus, the present study aimed to evaluate different intervals and numbers of ASM applications to determine the most effective regime for the management of bacterial spot on processing tomato.

\section{Materials and Methods}

ASM evaluation under field conditions. Five trials were performed between 2010 and 2011 (Table 1) at the Centro Nacional de Pesquisa de Hortaliças (Embrapa Hortaliças) in Brasília, Distrito Federal $\left(15^{\circ} 56^{\prime} 00^{\prime \prime} \mathrm{S}, 48^{\circ} 08^{\prime} 00^{\prime \prime} \mathrm{W}\right.$, and altitude of $\left.997 \mathrm{~m}\right)$ and in the experimental area at the Instituto Federal Goiano in Morrinhos,

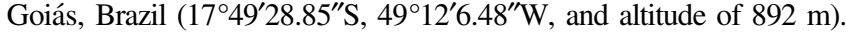
These experimental sites are located around the most important region of processing tomato crops in Brazil: the state of Goiás. Lime and fertilizer (N, P, K, and B) were applied for each trial at levels that were calculated based on soil analysis according to the recommendation for the state of Goiás. For all trials, 25-day-old seedlings of the commercial hybrid H9992 (Heinz Seeds) produced in a commercial

Table 1. Summary of the field trials on bacterial spot management by using acibenzolar-S-methyl treatments on processing tomato carried out in Brazil, showing location, dates of transplanting, inoculations, and harvest ${ }^{\mathrm{a}}$

\begin{tabular}{llccccc}
\hline Trials & Location $^{\mathbf{b}}$ & Transplanting & First inoculation & Second inoculation & \multicolumn{1}{c}{ Strainc $^{\mathbf{c}}$} & Harvest \\
\hline 1, Summer-fall, 2010 & Brasília, DF & 15 March & 1 April, infected & April, 14, spray & X. perforans T3 EH 2009-112 & 12 July \\
2, Summer-fall, 2010 & Morrinhos, GO & 18 March & 31 March, infected & April, 23, spray & X. perforans T3 EH 2009-112 & 16 July \\
3, Winter-spring, 2010 & Morrinhos, GO & 11 June & 17 June, infected & July, 28, spray & X. gardneri T2 EH 2006-52 & 5 October \\
4, Summer-fall, 2011 & Brasília, DF & 3 March & 17 March, infected & $\ldots$ & X. perforans T3 EH 2008-13 & 4 July \\
5, Winter-spring, 2011 & Brasília, DF & 17 June & 15 July, spray & $\ldots$ & X. gardneri T2 EH 2006-52 & 30 September \\
\hline
\end{tabular}

a For inoculation, "infected" = infected seedlings and "spray" = spraying $10^{7} \mathrm{CFU} \mathrm{m}{ }^{-1}$

${ }^{\mathrm{b}} \mathrm{DF}=$ Distrito Federal and GO = Goiás.

${ }^{c}$ Strains of Xanthomonas gardneri and $X$. perforans were used for inoculations according to the climatic conditions current in the beginning of planting (winter for $X$. gardneri and summer for X. perforans).

Table 2. Area under the disease progress curve (AUDPC) for bacterial spot and yield (YLD, $\mathrm{t} \mathrm{ha}^{-1}$ ) on processing tomato in response to different combinations of intervals and number of acibenzolar-S-methyl (ASM) applications in five trials carried out in Brasilia, Distrito Federal (trials 1, 4, and 5), and Morrinhos, Goiás (trials 2 and 3), Brazil, in the years 2010 (trials 1 and 2) and 2011 (trials 3, 4, and 5)

\begin{tabular}{|c|c|c|c|c|c|c|c|c|c|c|c|}
\hline \multicolumn{2}{|c|}{ Treatments } & \multicolumn{2}{|c|}{ Trial 1} & \multicolumn{2}{|c|}{ Trial 2} & \multicolumn{2}{|c|}{ Trial 3} & \multicolumn{2}{|c|}{ Trial 4} & \multicolumn{2}{|c|}{ Trial 5} \\
\hline Interval & $\overline{\text { Number }}$ & AUDPC & YLD & AUDPC & $\overline{\text { YLD }}$ & AUDPC & $\overline{\text { YLD }}$ & AUDPC & $\overline{\text { YLD }}$ & AUDPC & $\overline{\text { YLD }}$ \\
\hline 4 & 4 & $2,887.21^{*}$ & 82.46 & $1,765.67$ & 101.66 & $3,060.49$ & 66.11 & $2,071.11$ & 48.14 & $2,113.33 *$ & 35.62 \\
\hline 4 & 6 & $2,804.36^{*}$ & 79.40 & $1,404.17$ & 96.94 & $2,623.82$ & 56.74 & $1,709.75^{*}$ & 52.68 & $2,113.33 *$ & 27.36 \\
\hline 4 & 8 & $2,614.40^{*}$ & 81.05 & $1,655.00$ & 91.38 & $2,765.61$ & 50.00 & $1,457.27 *$ & $54.21 *$ & $2,076.67 *$ & 30.32 \\
\hline 4 & 10 & $2,460.30 *$ & 77.11 & $1,650.25$ & 81.71 & $2,553.30$ & 58.80 & $1,528.19 *$ & 50.53 & $2,021.67 *$ & 39.36 \\
\hline 7 & 4 & $3,029.30$ & 78.88 & $1,745.00$ & 111.62 & $2,791.53$ & 57.54 & $1,501.25^{*}$ & 51.16 & $2,058.33^{*}$ & 32.42 \\
\hline 7 & 6 & $2,342.30 * *$ & $94.22 * *$ & $1,465.50$ & 87.75 & $2,475.68$ & 55.99 & $1,489.31 *$ & $62.32 *$ & $1,848.33 *$ & 25.48 \\
\hline 7 & 8 & $2,152.00 * *$ & $93.04 * *$ & $1,547.00$ & 88.20 & $2,725.80$ & 57.82 & $1,347.08 * *$ & $60.02 *$ & $1,575.00^{*}$ & 36.96 \\
\hline 7 & 10 & $2,133.51 * *$ & 78.46 & $1,753.00$ & 117.23 & $2,720.43$ & 47.84 & $1,290.56^{* *}$ & 50.65 & $1,160.00 * *$ & 35.44 \\
\hline 10 & 4 & $2,473.33^{*}$ & 77.46 & $1,632.50$ & 105.26 & $2,776.32$ & 49.81 & $1,663.47 *$ & 51.63 & $1,940.00 *$ & 37.82 \\
\hline 10 & 6 & $2,463.67^{*}$ & 78.06 & $1,904.08$ & 110.17 & $2,870.67$ & 59.33 & $1,698.61^{*}$ & $56.35^{*}$ & $2,213.33$ & 34.41 \\
\hline 10 & 8 & $2,358.22 * *$ & 78.96 & $1,695.50$ & 102.77 & $2,880.28$ & 55.01 & $1,558.33^{*}$ & $58.28 *$ & $1,490.83 * *$ & 36.97 \\
\hline 10 & 9 & $2,322.59 * *$ & 79.05 & $1,745.50$ & 104.08 & $2,566.72$ & 55.29 & $1,574.44^{*}$ & $55.71 *$ & $1,661.67 *$ & 35.51 \\
\hline 14 & 4 & $3,045.14$ & 84.88 & $2,019.83$ & 98.77 & $2,793.07$ & 60.10 & $1,668.06^{*}$ & 48.82 & $2,783.33$ & 33.95 \\
\hline 14 & 6 & $2,745.70^{*}$ & 78.18 & $1,879.50$ & 90.05 & $2,724.64$ & 61.72 & $1,613.19 *$ & 49.67 & $2,694.17$ & 33.96 \\
\hline 14 & 7 & $2,900.60 *$ & 79.13 & $2,341.58$ & 102.26 & $2,536.54$ & 54.50 & $1,611.53^{*}$ & 52.22 & $2,505.00$ & 32.70 \\
\hline $\mathrm{CH}$ & $\ldots$ & $3,045.98$ & 79.38 & $1,813.83$ & 86.08 & $2,682.38$ & 49.70 & $2,042.22 *$ & 49.56 & $2,145.00$ & 33.48 \\
\hline Control & $\ldots$ & $3,486.64$ & 80.34 & $1,697.50$ & 90.13 & $2,724.42$ & 58.53 & $2,654.58$ & 39.80 & $2,743.33$ & 35.37 \\
\hline $\operatorname{Pr}>F$ & $\ldots$ & $<0.01$ & $<0.01$ & 0.14 & 0.88 & 0.26 & 0.30 & $<0.01$ & 0.02 & $<0.01$ & 0.63 \\
\hline $\mathrm{CV}(\%)^{\mathrm{b}}$ & $\cdots$ & 8.69 & 5.16 & 17.29 & 19.0 & 8.12 & 13.38 & 14.54 & 10.98 & 12.12 & 19.94 \\
\hline
\end{tabular}

${ }^{a}$ ASM applications were followed by copper hydroxide $(\mathrm{CH})$ weekly applications up to 90 days after transplanting. Asterisks: $*$ indicates significantly different from the water control by Dunnett's test $(P \leq 0.05)$ and ** indicates significantly different from the CH control by Dunnett's test $(P \leq 0.05)$.

${ }^{\mathrm{b}}$ Coefficient of variation.

Table 3. Analysis of variance and effects of the application interval (Int) and number of applications (Num) on area under disease progress curve (AUDPC) for bacterial spot and yield $\left(\mathrm{YLD}, \mathrm{tha}^{-1}\right.$ ) of processing tomato in five trials carried out in Brasilia, Distrito Federal (trials 1, 4, and 5), and Morrinhos, Goiás (trials 2 and 3), Brazil, in the years 2010 (trials 1 and 2) and 2011 (trials 3, 4, and 5)

\begin{tabular}{|c|c|c|c|c|c|c|c|c|c|c|c|}
\hline \multirow[b]{2}{*}{ Source $^{a}$} & \multirow[b]{2}{*}{$\mathbf{d f ^ { \mathbf { b } }}$} & \multicolumn{2}{|c|}{ Trial 1} & \multicolumn{2}{|c|}{ Trial 2} & \multicolumn{2}{|c|}{ Trial 3} & \multicolumn{2}{|c|}{ Trial 4} & \multicolumn{2}{|c|}{ Trial 5} \\
\hline & & AUDPC & YLD & AUDPC & YLD & AUDPC & YLD & AUDPC & YLD & AUDPC & YLD \\
\hline Int & 3 & $<0.01^{2}$ & $<0.01$ & 0.11 & 0.31 & 0.68 & 0.78 & 0.01 & 0.02 & $<0.01$ & 0.70 \\
\hline Num & 3 & $<0.01$ & 0.05 & 0.36 & 0.71 & 0.10 & 0.75 & 0.05 & 0.01 & $<0.01$ & 0.25 \\
\hline Int $\times$ Num & 8 & 0.04 & $<0.01$ & 0.56 & 0.40 & 0.28 & 0.69 & 0.45 & 0.68 & 0.09 & 0.71 \\
\hline Block & 2 & $<0.01$ & 0.30 & 0.45 & 0.18 & 0.0002 & 0.31 & 0.10 & $<0.01$ & 0.08 & 0.01 \\
\hline $\mathrm{CV}(\%)$ & $\ldots$ & 7.94 & 5.33 & 16.21 & 18.73 & 8.26 & 13.61 & 13.51 & 9.82 & 12.16 & 20.32 \\
\hline
\end{tabular}

a Sources of variation were considered significant when $P \leq 0.05 . \mathrm{CV}=$ coefficient of variation.

b Number of degrees of freedom. 

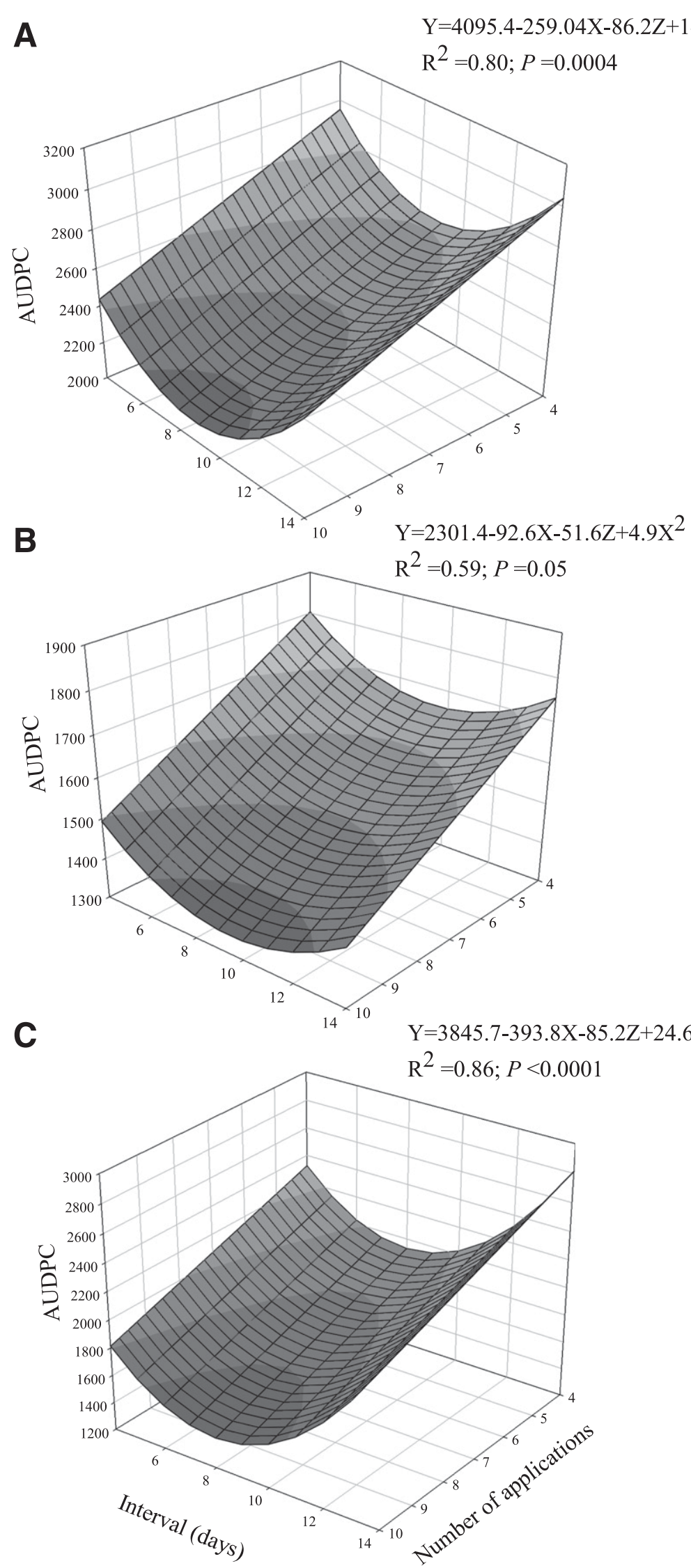

Fig. 1. Response-surface curves for the effect of intervals and numbers of acibenzolar-S-methyl applications on the estimated area under disease progress curve (AUDPC) for bacterial spot on processing tomato in three trials carried out in Brasília, Distrito Federal, Brazil, from A, March to July 2010; B, March to July 2011; and C, July to September 2011. All equation parameters were significant $(P \leq 0.05)$. 
nursery were transplanted. The seedlings were set in double rows with an internal spacing of $0.70 \mathrm{~m}$ and a distance of $1.10 \mathrm{~m}$ between the double rows. The spacing between plants was $0.37 \mathrm{~m}$, resulting in a density of 30,030 . The plants were sprinkler irrigated by a pivot system and the watering regime was similar to that employed for commercial crops at Morrinhos, which involved the weekly application of a 20-mm irrigation depth during the first month after transplanting and a 30-mm irrigation depth until approximately 14 weeks of cropping, when irrigation was stopped to promote fruit ripening.

The chemicals used in the treatments were ASM and copper hydroxide (CH; Kocide WDG, 53.8\% CH; DuPont do Brazil S.A.). They were applied according to their respective label doses (ASM and $\mathrm{CH}$ at 2.5 and $174.9 \mathrm{~g}$ of active ingredient [a.i.] per 100 liters, respectively). Four intervals between ASM applications $(4,7,10$, and 14 days) and four frequencies of applications (4, 6, 8, and 10 applications) were evaluated. The applications were initiated at 7 days after transplanting (DAT) and were performed for up to 90 DAT. This allowed the chemical applications to be ended 30 days before harvesting in order to follow the standard procedure in processing tomato crops in Brazil. In each ASM treatment, $\mathrm{CH}$ was applied weekly after ASM applications to complete 13 applications per growing season, with the exception for the treatments of 10-day and 14-day intervals between the ASM applications. In these treatments, the total number of applications was 9 and 7 , respectively, to follow the 90-day period of chemical application. $\mathrm{CH}$ and untreated plots served as negative and positive controls, respectively. The chemicals were applied with a backpack $\mathrm{CO}_{2}$ sprayer (HB PES 003; HerbCat) at $207 \mathrm{kPa}$ with double flat-spray nozzles adjusted to deliver a volume of 500 liters $\mathrm{ha}^{-1}$, which corresponded to the runoff point. The trials

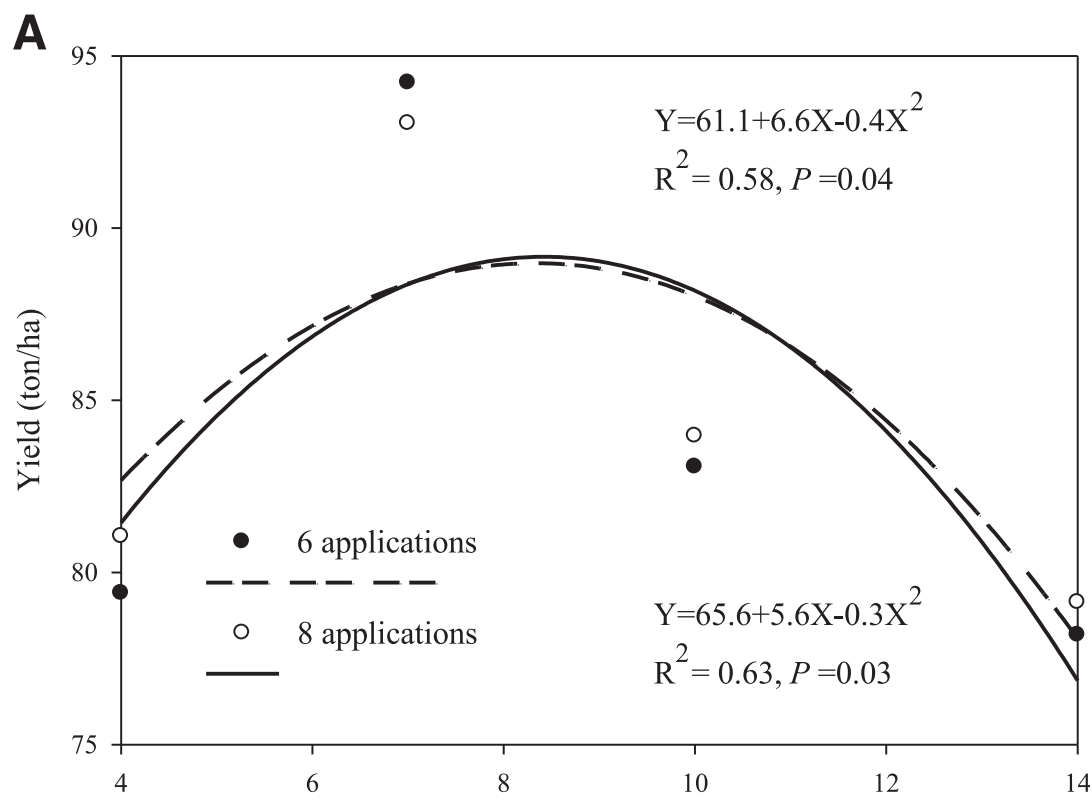

Interval between applications (days)

B

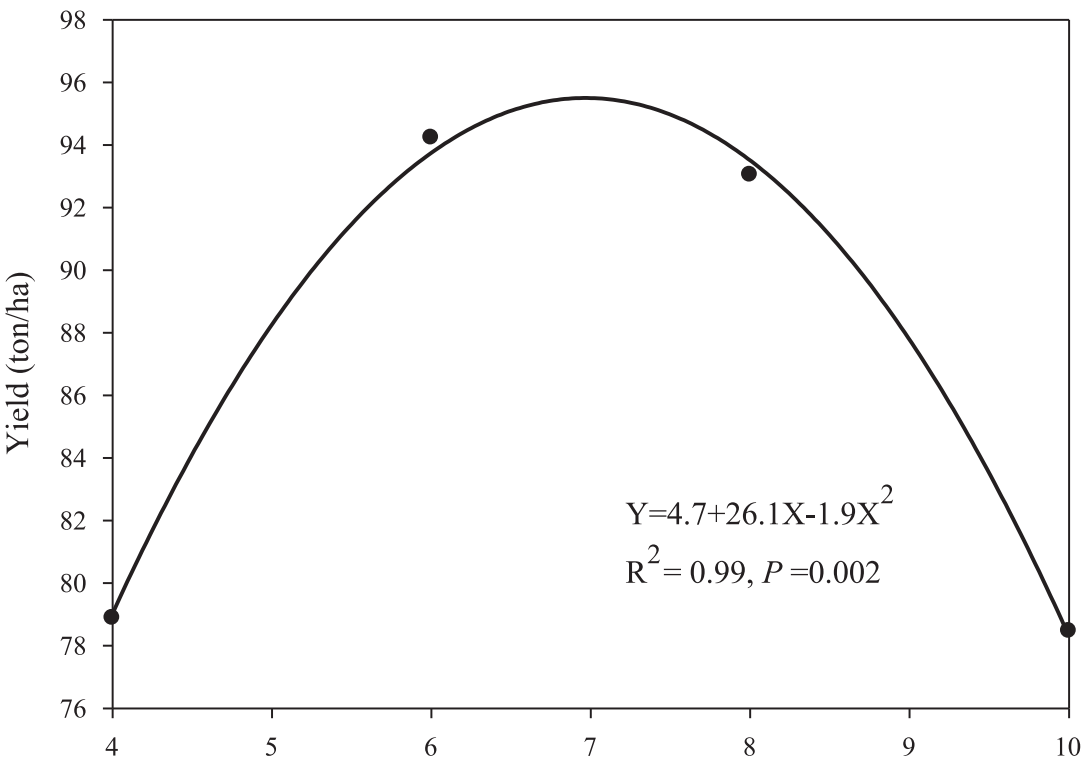

Number of applications

Fig. 2. Relationship between yield of processing tomato and interval between applications of acibenzolar-S-methyl (ASM) in A, treatments with six and eight ASM applications and B, number of applications in the treatment with weekly ASM applications in one trial carried out in Brasilia, Distrito Federal, Brazil (March to July 2010). All equation parameters were significant $(P \leq 0.05)$. 
were carried out in a complete randomized block design with three replicates, in a factorial arrangement (four intervals by four numbers of applications) with two check treatments ( $\mathrm{CH}$ treated or untreated). Each plot included 28 plants in two inner rows, surrounded by twin outer rows.

Copper-sensitive strains of $X$. perforans race T3 (EH 2008-13) and $X$. gardneri (EH 2009-112), from the Embrapa Hortaliças collection, were used for field inoculations (Table 1). The choice of the species was made based on the climatic conditions at planting (winter for $X$. gardneri and summer for X. perforans). This was because of the possible correlation of species fitness and temperatures (Araújo et al. 2011). In the trials $1,2,3$, and 4 , inoculated seedlings (six per row) were planted beside the field plots to aid the establishment of the bacterial spot epidemic, as described by Pontes et al. (2015). In trials 1,2, and 3, due to low relative humidity, bacterial suspension $\left(10^{7} \mathrm{CFU} \mathrm{ml^{-1 }}\right)$ was also sprayed on the plant surfaces to increase the disease pressure. In trial 5, the plants were inoculated only by spray inoculation. Disease severity was assessed weekly by two methods, according to the protocol described by Pontes et al. (2015) for evaluation of bacterial spot in processing tomato field trials. The first assessment method of the disease severity was taken up to 60 DAT. Disease severity was scored as mean estimated percentage of necrotic area per 24-leaflet sample per plot. Samples were collected at six equidistant points. After 60 DAT, disease severity was recorded based on a picture scale of progressive disease levels developed by QuezadoDuval et al. (2011), which considered the whole row. Bacterial spot severity data were used to calculate the area under the disease progress curve (AUDPC) per plot.

The fruit were harvested at 120 days after planting. The data collected included yield $\left(\mathrm{t} \mathrm{ha}^{-1}\right)$, percentage of ripened fruit (red or changing to red fruit), and levels of soluble solids of mature fruit (five fruit per plot) measured with a refractometer (PAL-1 pocket refractometer; Atago). Whenever statistical differences among treatments were detected in terms of yield, the benefit/cost ratio was calculated according to the following equation adapted from Prest and Turvey (1965):

$$
\frac{B}{C}=\sum_{t=0}^{n} \frac{B}{C(1+r)^{t}}
$$

where $B$ is the revenue, $C$ represents the cost variables (prices of both products and application services), $t=$ time, $n=$ the time limit

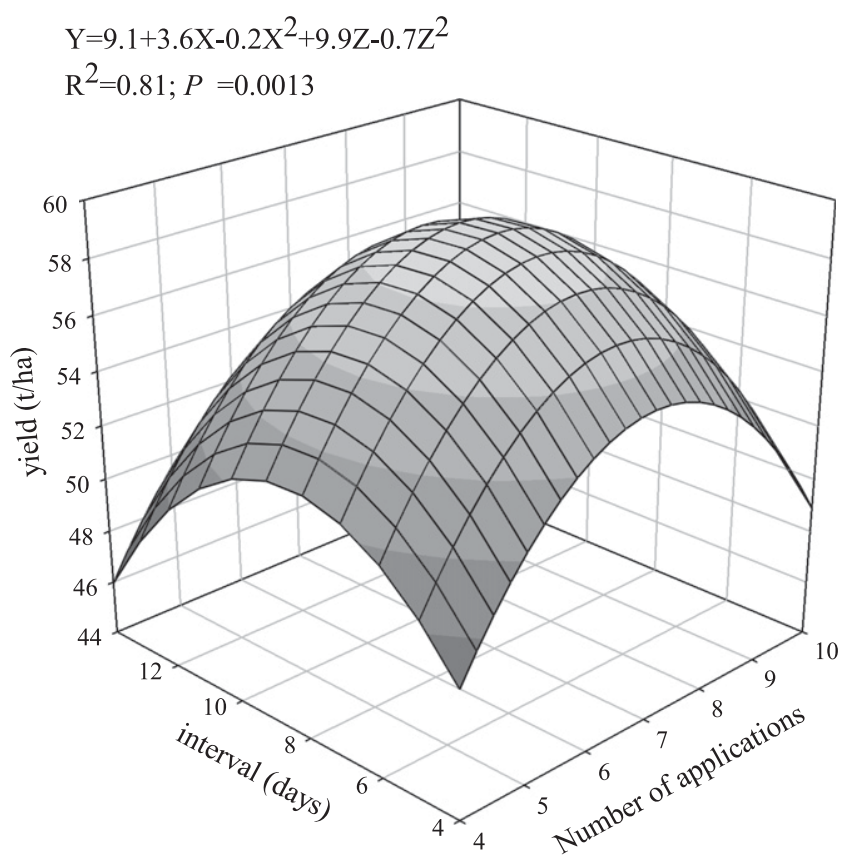

Fig. 3. Response-surface curve for the effect of intervals and numbers of acibenzolarS-methyl applications on the estimated value of tomato crop yield in one trial carried out in Brasilia, Distrito Federal, Brazil (March to July 2011). All equation parameters were significant $(P \leq 0.05)$.
(120 days), and $r=$ the adopted discount rate. When $B / C>1$, the treatment is considered economically viable. The discount rate used in the analyses as a representation of the value of money banking income over time was $0.65 \%$ per month, referring to the average real interest rate of a savings account over the last 8 years.

Persistence of ASM in controlling bacterial spot. To evaluate the duration of the effect of ASM (2.5 g a.i. per 100 liters) in controlling bacterial spot, two greenhouse trials were performed with the tomato hybrid H9992. The trials were carried out in a complete randomized block design with three replicates, in a factorial arrangement (interval between the last application of ASM and the inoculation date versus one or two applications prior to inoculation). Each replicate plot included three plants. Control plants were sprayed only with water. The first ASM application was done just after transplanting, which occurred when seedlings reached the two- to three-trueleaf stage, 15 days after sowing. They were transplanted into pots (1 liter) containing autoclaved substrate (100 liter of soil, 100 liter of sand, $300 \mathrm{~g}$ of NPK 4-14-8 fertilizer, $500 \mathrm{~g}$ of lime, $40 \mathrm{~g}$ of ammonium sulfate, and 20 liter of burned rice husks). The intervals between the last ASM application and inoculation were 9, 6, 3, 1, and 0 days. In the treatments with two ASM applications prior to inoculation, there was an interval of 7 days between the first and second applications. A strain of X. perforans race T3 (EH 2008-13) was used for inoculation. In the first trial, the plants were inoculated 31 days after sowing by spraying the leaf surfaces with a hand-held sprayer containing bacterial suspension at approximately $5 \times 10^{7} \mathrm{CFU} \mathrm{ml}{ }^{-1}$. In the second trial, bacterial concentration was increased to $5 \times 10^{8} \mathrm{CFU} \mathrm{ml}^{-1}$, in order to increase bacterial spot pressure. After inoculation, the plants were maintained in a moist chamber achieved by a mist regime of 5-min intervals for $2 \mathrm{~h}$. At 9 days after inoculation, all leaflets of the third leaf of the plants per replicate plot were collected and scanned (Multifunctional Printer Deskjet F4180; HP). Digital images were analyzed using the computer software Assess 2.0 (Image Analysis Software for Disease Quantification; APS) to calculate the percentage of necrotic area per leaflet.

Validation of the best treatment in commercial tomato production. The efficacy of the most promising treatment from the field results was evaluated in a commercial processing tomato crop of H9553 (Heinz Seeds)

Table 4. Benefit/cost ratio (B/C) of treatments with different numbers and intervals of acibenzolar-S-methyl (ASM) applications and treatment with copper hydroxide applications, based on the yield data from two trials carried out between March and July 2010 and 2011, respectively, in Brasilia, Distrito Federal, Brazil ${ }^{\mathrm{a}}$

\begin{tabular}{|c|c|c|c|c|c|}
\hline \multirow{2}{*}{\multicolumn{2}{|c|}{$\begin{array}{l}\text { ASM-CH } \\
\text { applications }\end{array}$}} & \multicolumn{2}{|c|}{ Trial 1} & \multicolumn{2}{|c|}{ Trial 4} \\
\hline & & \multirow{2}{*}{$\begin{array}{c}\text { Increase } \\
\text { (t/ha) }\end{array}$} & \multirow{2}{*}{$\begin{array}{l}\mathrm{B} / \mathrm{C} \\
\text { ratio }\end{array}$} & \multirow{2}{*}{$\begin{array}{c}\text { Increase } \\
(\mathrm{t} / \mathrm{ha})\end{array}$} & \multirow{2}{*}{$\begin{array}{l}\text { C/B } \\
\text { ratio }\end{array}$} \\
\hline Interval & Number $^{\mathbf{b}}$ & & & & \\
\hline 4 & $4(10)$ & 2.12 & 0.36 & 8.34 & 1.43 \\
\hline 4 & $6(9)$ & -0.94 & -0.15 & 12.88 & 2.04 \\
\hline 4 & $8(8)$ & 0.71 & 0.10 & 14.41 & 2.12 \\
\hline 4 & $10(7)$ & -3.23 & -0.44 & 10.73 & 1.48 \\
\hline 7 & $4(9)$ & -1.46 & -0.27 & 11.36 & 2.09 \\
\hline 7 & $6(7)$ & 13.88 & 2.52 & 22.52 & 4.09 \\
\hline 7 & $8(5)$ & 12.7 & 2.28 & 20.22 & 3.63 \\
\hline 7 & $10(3)$ & -1.88 & -0.33 & 10.85 & 1.93 \\
\hline 10 & $4(8)$ & -2.88 & -0.57 & 11.83 & 2.35 \\
\hline 10 & $6(5)$ & -2.28 & -0.49 & 16.55 & 3.53 \\
\hline 10 & $8(2)$ & -1.38 & -0.32 & 18.48 & 4.26 \\
\hline 10 & $9(0)$ & -1.29 & -0.33 & 15.91 & 4.01 \\
\hline 14 & $4(6)$ & 4.54 & 1.08 & 9.02 & 2.14 \\
\hline 14 & $6(2)$ & -2.16 & -0.62 & 9.87 & 2.85 \\
\hline 14 & $7(0)$ & -1.21 & -0.39 & 12.42 & 4.03 \\
\hline $\mathrm{CH}$ & (13) & -0.94 & -0.18 & 9.76 & 1.84 \\
\hline
\end{tabular}

${ }^{a}$ Increase in yield compared with the untreated control. Prices for ASM (BRL $1.17 \mathrm{~g}^{-1}$ ), CDH (BRL $0.016 \mathrm{~g}^{-1}$ ), tomato (BRL $146.20 \mathrm{t}^{-1}$ ), and application services (BRL $33.33 \mathrm{ha}^{-1}$ ) were determined based on the average prices over the last 8 years.

${ }^{b}$ Values in parentheses correspond to the number of copper hydroxide $(\mathrm{CH})$ applications. 
in Itaberaí, State of Goiás $\left(49^{\circ} 43^{\prime} 571^{\prime \prime} \mathrm{W}, 1^{\circ} 03^{\prime} 97.1^{\prime \prime} \mathrm{S}\right.$, and altitude of $749 \mathrm{~m}$ ) from March to July 2010. Bacterial spot occurred early in the growing season and was caused by $X$. perforans. The field was sprinkler irrigated by a pivot system. Two strips of nine double rows (approximately $16 \mathrm{~m}$ wide) $600 \mathrm{~m}$ in length were treated with the best ASM program described above. This program was compared with the farmer's standard bacterial spot control program, which comprised $\mathrm{CH}$ applications initiated in the second week after planting. Ratios of application of ASM and $\mathrm{CH}$ were as described for the field experiments. However, the spray volume was 200 liters ha ${ }^{-1}$ during the first 2 weeks, 300 liters ha $^{-1}$ in the following week, and 500 liters $\mathrm{ha}^{-1}$ in subsequent applications. For disease severity evaluation, 30 symptomatic leaflets were randomly collected at each of 15 points along a plant line into the ASM-CH program strip, and also along the adjacent conventional program. The points were about 20 to $30 \mathrm{~m}$ apart from each other. The percent necrotic area of the collected leaflets was established as described for the greenhouse trials. At 120 days after planting, the tomato fruit of 10 randomly chosen plants representing each application program were harvested, as described for severity scoring, and the yield, plant height, percentage of ripe and rotten fruit, and soluble solids content were evaluated.

Statistical analyses. Analysis of variance was performed after confirming the normality of the error and the homogeneity of variance. Dunnett's test was used to compare the treatments with the two check treatments for the five field trials. Regression analyses were performed for the quantitative variables AUDPC and yield $(P \leq 0.05)$ whenever significant differences among treatments were detected. The two greenhouse experiments were statistically analyzed individually. A $t$ test was performed for the on-farm validation. All analyses were performed with SAS 9.2 software (SAS Institute) using the UNIVARIATE and GLM procedures.

\section{Results}

Effect of ASM on bacterial spot in field trials. Significant differences between the treatments regarding disease severity or yield were detected in three out of the five trials. In trial 1, all ASM application

Table 5. Severity of bacterial spot on processing tomato plants under greenhouse conditions with one or two acibenzolar-S-methyl applications before inoculation at different intervals between the last application and inoculation ${ }^{\mathrm{a}}$

\begin{tabular}{|c|c|c|c|c|}
\hline \multirow[b]{2}{*}{ Interval } & \multicolumn{2}{|c|}{ Trial 1} & \multicolumn{2}{|c|}{ Trial 2} \\
\hline & $\begin{array}{c}\text { One } \\
\text { application }\end{array}$ & $\begin{array}{c}\text { Two } \\
\text { applications }\end{array}$ & $\begin{array}{c}\text { One } \\
\text { application }\end{array}$ & $\begin{array}{c}\text { Two } \\
\text { applications }\end{array}$ \\
\hline 0 days & 8.87 & $3.45^{*}$ & 47.93 & $12.44 * *$ \\
\hline 1 day & 4.00 & $3.38 *$ & 36.00 & $10.03 * *$ \\
\hline 2 days & $3.33 *$ & $3.31 *$ & $28.73 *$ & $8.76 * *$ \\
\hline 3 days & 5.86 & $2.10 * *$ & 45.56 & $6.90 * *$ \\
\hline 6 days & 5.93 & $3.07 * *$ & 45.53 & $12.88 * *$ \\
\hline 9 days & 6.78 & 4.36 & 44.08 & 40.12 \\
\hline Control & \multicolumn{2}{|c|}{6.63} & \multicolumn{2}{|c|}{44.94} \\
\hline $\mathrm{CV}(\%)^{\mathrm{b}}$ & \multicolumn{2}{|c|}{8.25} & \multicolumn{2}{|c|}{9.48} \\
\hline
\end{tabular}

a Inoculation in trials 1 and 2 used bacterial suspension at concentration of $5 \times$ $10^{7}$ and $5 \times 10^{8} \mathrm{CFU} \mathrm{m}{ }^{-1}$, respectively. Data analyzed based on $\sqrt{\frac{x}{2}+1}$ transformed values. Means followed by $*$ or $* *$ are significantly different from the control by Dunnett's test at 5 and $1 \%$ probability levels, respectively.

${ }^{b}$ Coefficient of variation. intervals resulted in a significant reduction of disease severity after six applications relative to the checks (Table 2). Similar results were observed for trials 4 and 5. However, significant differences in yield were observed only for trials 1 and $4(P=0.0002$ and 0.02 , respectively). In trial 5, a natural Begomovirus outbreak occurred, reducing plant growth and yield. Thus, although differences between treatments regarding bacterial spot severity were observed, there was no effect on tomato yield $(P=0.63)$. No significant difference was observed for the variables ripe fruit and soluble solid content in the five trials.

The factors "interval between applications" and "number of applications" significantly affected AUDPC in trials 1,4 , and 5 and yield in trials 1 and 4 (Table 3 ). In trials 1, 4, and 5, there was a greater reduction in AUDPC values as the number of ASM applications increased (Fig. 1). Based on regression analysis, the intervals between applications that resulted in the lowest AUDPC values for trials 1, 4 , and 5 were estimated to be $8.71,9.51$, and 8 days, respectively.

Regarding yield, a significant effect of the interaction between interval between applications and number of applications was detected $(P=0.0019)$ only in trial 1 . In this trial, when evaluating the effect of interval between applications for each level of number of applications, a significant effect was observed only with six and eight applications $(P=0.02$ and 0.002 , respectively). The intervals between applications estimated to achieve the maximum yield with six and eight applications were 7.83 and 8.51 days, respectively (Fig. 2A). According to the analysis of the effect of the number of applications for the levels of the interval between applications, there was only an effect for the interval of 7 days between applications $(P=0.02)$, and maximum yield was estimated with 6.96 applications (Fig. 2B). For trial 4, the ideal combination of the factors to achieve the best yield was seven applications at 8.64-day intervals (Fig. 3), similar to that of trial 1.

When analysis of the benefit/cost ratio was based on the yields from trial 1, there was an increase in yield only in the treatments with 6 and 8 weekly ASM applications compared with the negative control (Table 4). In trial 4, all treatments provided satisfactory benefit/ cost ratios (>1). The greatest values were observed in treatments with eight ASM applications at 7- and 10-day intervals.

Persistence of ASM in controlling bacterial spot. The two greenhouse trials generated similar results in terms of the efficacy of ASM treatments. With one ASM application, disease severity decreased only with an interval of 2 days between application and inoculation (Table 5). With two ASM applications, bacterial spot control occurred with intervals from 0 to 6 days. After 9 days, ASM application did not reduce disease severity. For both trials, reapplication of the product prolonged the effect of ASM and increased the efficiency of bacterial spot control relative to one application.

Evaluation of the ASM-CH integrated program in a commercial processing tomato field. The ASM-CH program with seven weekly applications of ASM followed by six of $\mathrm{CH}$ was chosen, according to the regression analysis, for the on-farm validation. In the comparison with the standard $\mathrm{CH}$ program, there was a significant reduction of bacterial spot severity on tomato plants $(P=$ $0.04)$ and on the percentage of rotten fruit $(P=0.04)$ (Table 6). However, this reduction did not lead to an increase in the yield, with no significant difference detectable between the two protection programs $(P=0.83)$. In addition, there were no significant differences

Table 6. Severity of bacterial spot and tomato production components with an acibenzolar-S-methyl (ASM)-copper hydroxide $(\mathrm{CH})$ program and a standard weekly of copper program $(\mathrm{CH})$ for the commercial production of processing tomato ${ }^{\mathrm{a}}$

\begin{tabular}{|c|c|c|c|c|c|c|c|}
\hline Treatment & Severity (\%) & Yield $\left(t h^{-1}\right)$ & Brix $^{b}$ & Industrial yield $\left(t \mathrm{ha}^{-1}\right)^{\mathrm{c}}$ & Plant height (m) & Ripe fruit (\%) & Rotten fruit (\%) \\
\hline ASM-CH & 19.71 & 95.54 & 4.16 & 12.56 & 1.44 & 88.42 & 0.36 \\
\hline $\mathrm{CH}$ & 24.23 & 96.37 & 3.92 & 11.76 & 1.44 & 86.68 & 1.42 \\
\hline $\operatorname{Pr}>F$ & 0.04 & 0.83 & 0.07 & 0.68 & 0.63 & 0.51 & 0.04 \\
\hline $\mathrm{CV}(\%)^{\mathrm{d}}$ & 25.05 & 12.91 & 7.37 & 12.23 & 9.05 & 37.98 & 17.71 \\
\hline
\end{tabular}

a ASM-CH program consisted of seven weekly applications of ASM followed by six weekly applications of CH.

${ }^{\mathrm{b}}$ Industrial yield determined using the equation: Yield $\times$ Brix $\times$ Maturation $/ 28$.

c Brix of processed pulp.

$\mathrm{d}$ Coefficient of variation. 
for soluble solids content $(P=0.07)$, industrial yield $(P=0.68)$, plant height $(P=0.63)$, and ripe fruit $(P=0.51)$.

\section{Discussion}

As observed in other studies (Louws et al. 2001; Obradovic et al. 2004, 2005), ASM can decrease the severity of tomato bacterial spot disease in the field. However, different application schemes influenced the efficacy in controlling the disease. In three of five trials, we demonstrated that some ASM-CH treatments were statistically better than the untreated control. However, it is important to mention that the two trials that resulted in no significant differences among the treatments were those carried out in Morrinhos. In the first one of those, the bacterial spot severity was lower than in the other trials (Table 2). In fact, an average disease severity of $33.5 \%$ was observed for the untreated control plots in this trial, which was lower than those of trials 1,4 , and 5 (53.1, 73.3, and $81.6 \%$, respectively). Thus, differences between treatments and untreated control were more difficult to detect. On the other hand, in the second trial (June to October 2010), intense leaf necrosis (average disease severity of $74.5 \%$ ) was observed due to a mixed infection of bacterial spot and Septoria leaf spot. The effect of an ASM-CH integrated program on Septoria leaf spot has not been established. Based on the greenhouse trials, the effect of ASM applications in reducing bacterial spot severity was not perceptible from the ninth day after application, regardless of the number of applications. Scarponi et al. (2001) observed that, although ASM molecules translocate rapidly through tomato plant tissues, their concentrations dropped to negligible levels after 72 h. Similarly, Herman et al. (2007) reported a drastic reduction in the expression of the gene that encodes the acidic pathogenesis-related (PR)-1 protein (a marker gene for the induction of SAR) 3 days after ASM applications. However, Benhamou and Bélanger (1998) observed a rapid formation of barriers against Fusarium oxysporum $\mathrm{f}$. sp. radicis-lycopersici infection in tomato plants, even with a 4-day interval between ASM application and inoculation. Thaler et al. (1999) reported effects of ASM applications on SARrelated genes up to 5 days after application to tomato plants, although the levels were only slightly higher than those observed in the negative check. Thus, according to this and other studies (Cavalcanti et al. 2006a,b; Huang et al. 2012), the effect of ASM in maintaining SAR does not extend for more than 9 days.

There was an increase in bacterial spot control with two ASM applications before inoculation. This result confirms observations by Herman et al. (2007), who reported an additional increase in PR-1 gene expression after a second ASM application, indicating that there is a cumulative effect. However, a large number of applications can also lead to an energy expenditure that may compromise yield. Kuhn and Pascholati (2010) observed a correlation between the number of ASM applications and reduction of the vegetative growth of bean plants. Decreased yields of various crops due to ASM applications have been attributed to the energy cost associated with the induction of resistance (Gent and Schwartz 2005; Huang et al. 2012; Kuhn and Pascholati 2010; Romero et al. 2001; Walters and Fountaine 2009). Thus, there is a limit of applications after which ASM hinders crop development and reduces yield. The results of the present study indicated that the number of ASM applications should not exceed seven in the processing tomato growing conditions in Central Brazil, which is below the recommended number of applications for the commercial product (Andrei 2013).

The interval between ASM applications in the field should not be excessively long. Similar observations were recently reported (Huang et al. 2012) when evaluating weekly and biweekly intervals. Under the conditions of our experiments, the ideal interval between applications was 8 to 10 days. The combination of these intervals with seven ASM applications resulted in a period of 56 to 70 DAT for ASM use. After this period, other products should be used to control bacterial spot, such as $\mathrm{CH}$, in order to maintain the integrity of the canopy up to 90 DAT and avoid sunscald of fruit. In addition to copper, other promising compounds recently evaluated for the control of bacterial spot in tomato such as cymoxanil, famoxadone, and pyraclostrobin could be used (Fayette et al. 2012; Itako et al. 2015).
ASM has potential as a tool in an integrated bacterial spot control program on processing tomato. This would allow for a reduction of the number of copper applications during a growing season, which could reduce selective pressure on bacterial spot pathogen populations and reduce copper accumulation in the soil (Bernard et al. 2009; Komárek et al. 2010; Loland and Singh 2004). In addition, the on-farm experiment suggests an improvement in the quality of tomato fruit with the use of the CH-ASM integrated program; namely, the increase in the soluble solids content and the reduction of rotten fruit. These are important features for the pulp production efficacy in the processing tomato industry.

Despite the positive results, the benefit/cost ratio may be considered null or negative when the yield improvement is low or insignificant. To control plant disease, ASM must be applied preventatively. However, under conditions of low or no disease pressure, energy expenditure with resistance induction may reduce yield. Thus, based on the history of previous tomato crops at the site, such aspects should be taken into consideration before using the proposed ASM-CH integrated program. This study provides evidence for the use of ASM as a promising tool for tomato bacterial spot management, and indicates the need to limit the number of ASM applications to avoid reduction of processing tomato yield.

\section{Acknowledgments}

We thank the Fundação de Amparo à Pesquisa do Estado de Minas Gerais (FAPEMIG) for a D.Sc. fellowship to N. C. Pontes, the Coordenação de Apoio ao Pessoal do Ensino Superior (CAPES) for financial support (grant 009/2009 CAPES/MCT-FINEP), R. Sant'Ana from Cargill Foods Brazil for supporting the validation work in the commercial area, A. M. Araújo from Embrapa for field assistance, and E. S. G. Mizubuti for revision of the manuscript.

\section{Literature Cited}

Abbasi, P. A., Al-Dahmani, J., Sahin, F., Hoitink, H. A. J., and Miller, S. A. 2002a Effect of compost amendments on disease severity and yield of tomatoes in conventional and organic production systems. Plant Dis. 86:156-161.

Abbasi, P. A., Soltani, N., Cuppels, D. A., and Lazarovits, G. 2002b. Reduction of bacterial spot disease severity on tomato and pepper plants with foliar applications of ammonium lignosulfonate and potassium phosphate. Plant Dis. 86:1232-1236.

Adaskaveg, J. E., and Hine, R. B. 1985. Copper tolerance and zinc sensitivity of Mexican strains of Xanthomonas campestris pv. vesicatoria, causal agent of bacterial spot of pepper. Plant Dis. 69:993-996.

Andrei, E. 2013. Compêndio de Defensivos Agrícolas, 9th ed. Andrei Press, São Paulo, SP, Brazil.

Araújo, E. R., Costa, J. R., Pontes, N. C., and Quezado-Duval, A. M. 2015. Xanthomonas perforans and $X$. gardneri associated with bacterial leaf spot on weeds in Brazilian tomato fields. Eur. J. Plant Pathol. 143:543-548.

Araújo, E. R., Pereira, R. C., Ferreira, M. A. S. V., Café-Filho, A. C., Moita, A. W., and Quezado-Duval, A. M. 2011. Effect of temperature on pathogenicity components of tomato bacterial spot and competition between Xanthomonas perforans and X. gardneri. Acta Hortic. 914:39-42.

Benhamou, N., and Bélanger, R. R. 1998. Benzothiadiazole-mediated induced resistance to Fusarium oxysporum $\mathrm{f}$. sp. radicis-lycopersici in tomato. Plant Physiol. 118:1203-1212.

Bernard, L., Maron, P. A., Mougel, C., Nowak, V., Lévêque, J., Marol, C., Balesdent, J., Gibiat, F., and Ranjard, L. 2009. Contamination of soil by copper affects the dynamics, diversity, and activity of soil bacterial communities involved in wheat decomposition and carbon storage. Appl. Environ. Microbiol. 75:7565-7569.

Cavalcanti, F. R., Resende, M. L. V., Lima, J. P. M. S., Silveira, J. A. G., and Oliveira, J. T. A. 2006a. Activities of antioxidant enzymes and photosynthetic responses in tomato pre-treated by plant activators and inoculated by Xanthomonas vesicatoria. Physiol. Mol. Plant Pathol. 68:198-208.

Cavalcanti, F. R., Resende, M. L. V., Zacaroni, A. B., Ribeiro Júnior, P. M., Costa, J. C. B., and Souza, R. M. 2006b. Acibenzolar-S-metil e Ecolife na indução de respostas de defesa do tomateiro contra a mancha bacteriana (Xanthomonas vesicatoria). Fitopatol. Bras. 31:372-380.

Coqueiro, D. S. O., Maraschin, M., and Di Piero, R. M. 2011. Chitosan reduces bacterial spot severity and acts in phenylpropanoid metabolism in tomato plants. J. Phytopathol. 159:488-494.

Fayette, J., Roberts, P. D., Pernezny, K. L., and Jones, J. B. 2012. The role of cymoxanil and famoxadone in the management of bacterial spot on tomato and pepper and bacterial leaf spot on lettuce. Crop Prot. 31:107-112.

Fontenelle, A. D. B., Guzzo, S. D., Lucon, C. M. M., and Harakava, R. 2011. Growth promotion and induction of resistance in tomato plant against Xanthomonas euvesicatoria and Alternaria solani by Trichoderma spp. Crop Prot. 30:1492-1500.

Gent, D. H., and Schwartz, H. F. 2005. Management of Xanthomonas leaf blight of onion with a plant activator, biological control agents, and copper bactericides. Plant Dis. 89:631-639.

Gilardi, G., Gullino, M. L., and Garibaldi, A. 2010. Evaluation of spray programmes for the management of leaf spot incited by Pseudomonas syringae pv. syringae on tomato cv. Cuore di bue. Crop Prot. 29:330-335. 
Herman, M. A. B., Restrepo, S., and Smart, C. D. 2007. Defense gene expression patterns of three SAR-induced tomato cultivars in the field. Physiol. Mol. Plant Pathol. 71:192-200.

Huang, C.-H., Vallad, G. E., Zhang, S., Wen, A., Balogh, B., Figueiredo, J. F. L., Behlau, F., Jones, J. B., Momol, M. T., and Olson, S. M. 2012. Effect of application frequency and reduced rates of acibenzolar-S-methyl on the field efficacy of induced resistance against bacterial spot on tomato. Plant Dis. 96:221-227.

Itako, A. T., Tolentino Júnior, J. B., Silva Júnior, T. A. F., Soman, J. M., and Maringoni, A. C. 2015. Chemical products induce resistance to Xanthomonas perforans in tomato. Braz. J. Microbiol. 46:701-706.

Jones, J. B., Lacy, G. H., Bouzar, H., Stall, R. E., and Schaad, N. W. 2004. Reclassification of the xanthomonads associated with bacterial spot disease of tomato and pepper. Syst. Appl. Microbiol. 27:755-762.

Jones, J. B., Pohronezny, R. E., Stall, R. E., and Jones, J. P. 1986. Survival of Xanthomonas campestris pv. vesicatoria in Florida on tomato crop residue, weeds, seeds, and volunteer tomato plants. Phytopathology 76:430-434.

Komárek, M., Cadková, E., Chrastný, V., Bordas, F., and Bollinger, J.-C. 2010. Contamination of vineyard soils with fungicides: A review of environmental and toxicological aspects. Environ. Int. 36:138-151.

Kuhn, O. J., and Pascholati, S. F. 2010. Custo adaptativo da indução de resistência em feijoeiro mediada pela rizobactéria Bacillus cereus ou acibenzolar-S-metil: Atividade de enzimas, síntese de fenóis e lignina e biomassa. Summa Phytopathol. 36:107-114.

Loland, J. O., and Singh, B. R. 2004. Copper contamination of soil and vegetation in coffee orchards after long-term use of $\mathrm{Cu}$ fungicides. Nutr. Cycl. Agroecosyst. 69:203-211.

Louws, F. J., Wilson, M., Campbell, H. L., Cuppels, D. A., Jones, J. B., Shoemaker, P. B., Sahin, F., and Miller, S. A. 2001. Field control of bacterial spot and bacterial speck of tomato using a plant activator. Plant Dis. 85:481-488.

Lucas, G. C., Alves, E., Pereira, R. B., Zacaroni, A. B., Perina, F. J., and De Souza, R. M. 2012. Indian clove essential oil in the control of tomato bacterial spot. J. Plant Pathol. 94:45-51.

Melo, P. C. T., and Fonte, L. C. 2011. Brazil processing tomato season 2010: Results and future perspectives. Tomato News 3:15-19.

Mirik, M., Aysan, Y., and Cinar, O. 2007. Copper-resistance strains of Xanthomonas axonopodis pv. vesicatoria (Doidge) Dye in the Eastern Mediterranean region of Turkey. J. Plant Pathol. 89:153-154.

Obradovic, A., Jones, J. B., Momol, M. T., Balogh, B., and Olson, S. M. 2004. Management of tomato bacterial spot in the field by foliar applications of bacteriophages and SAR inducers. Plant Dis. 88:736-740.

Obradovic, A., Jones, J. B., Momol, M. T., Olson, S. M., Jackson, L. E., Balogh, B., Guven, K., and Iriarte, F. B. 2005. Integration of biological control agents and systemic acquired resistance inducers against bacterial spot on tomato. Plant Dis. 89:712-716

Pontes, N. C., Nascimento, A. R., Moita, A. W., Maffia, L. A., De Oliveira, J. R., and Quezado-Duval, A. M. 2015. Establishment of a procedure for bacterial spot inoculation and assessment in processing tomato field trials. Trop. Plant Pathol. 40:339-344.
Potnis, N., Timilsina, S., Strayer, A., Shantharaj, D., Barak, J. D., Paret, M. L., Vallad, G. E., and Jones, J. B. 2015. Bacterial spot of tomato and pepper: Diverse Xanthomonas species with a wide variety of virulence factors posing a worldwide challenge. Mol. Plant Pathol. 16:907-920.

Prest, A. R., and Turvey, R. 1965. Cost-benefit analysis: A survey. Econ. J. 75 683-735.

Quezado-Duval, A. M., Inoue-Nagata, A. K., Reis, A., Pinheiro, J. B., Lopes, C. A., Araújo, E. R., Fontenelle, M. R., Costa, J. R., Guimarães, C. M. N., Rossato, M., Becker, W. F., Costa, H., Ferreira, M. A. S. V., and Destéfano, S. A. L. 2013. Levantamento de doenças e mosca-branca em tomateiro em regiões produtoras no Brasil. Embrapa Hortaliças Bol. Pesqui. Desenvolvimento 100:1-36.

Quezado-Duval, A. M., Leite, R. P., Jr., Lima, M. F., and Camargo, L. E. A. 2005 Diversity of Xanthomonas spp. associated with bacterial spot of processing tomatoes in Brazil. Acta Hortic. 695:101-108.

Quezado-Duval, A. M., and Lopes, C. A. 2010. Mancha bacteriana: Uma atualização para o sistema de produção integrada de tomate indústria. Embrapa Hortaliças Circ. Tec. 84:1-24.

Quezado-Duval, A. M., Nascimento, A. R., Pontes, N. C., Moita, A. W., Assunção, A., Golynski, A., Inoue-Nagata, A. K., Oliveira, R. T., Castro, Y. O., and Melo, B. J. 2014. Desempenho de híbridos de tomate para processamento industrial em pressão de begomovirose e de mancha-bacteriana. Hortic. Bras. 32: 446-452.

Quezado-Duval, A. M., Pontes, N. C., Nascimento, A. R., and Moita, A. W. 2011 Metodologia de avaliação da severidade da mancha bacteriana em tomateiro para processamento industrial. Embrapa Hortaliças Bol. Pesqui. Desenvolvimento 73:1-24.

Romero, A. M., Kousik, C. S., and Ritchie, D. F. 2001. Resistance to bacterial spot in bell pepper induced by acibenzolar-S-methyl. Plant Dis. 85 189-194.

Scarponi, L., Buonaurio, R., and Martinetti, L. 2001. Persistence and translocation of a benzothiadiazole derivative in tomato plants in relation to systemic acquired resistance against Pseudomonas syringae pv. tomato. Pest Manage. Sci. 57:262-268.

Stall, R. E., Jones, J. B., and Minsavage, G. V. 2009. durability of resistance in tomato and pepper to Xanthomonads causing bacterial spot. Annu. Rev. Phytopathol. 47:265-284

Thaler, J. S., Fidantsef, A. L., Duffey, S. S., and Bostock, R. M. 1999. Tradeoffs in plant defense against pathogens and herbivores: A field demonstration of chemical elicitors of induced resistance. J. Chem. Ecol. 25 1597-1609.

Walters, D. R., and Fountaine, J. M. 2009. Practical application of induced resistance to plant diseases: An appraisal of effectiveness under field conditions. J. Agric. Sci. 147:523-535.

WPTC. 2015. World production estimate of tomatoes for processing (in 1000 metric tonnes). Online publication. The World Processing Tomato Council. http://www.wptc.to/releases-wptc 